\title{
Ideologi Islam Tradisionalis dalam Tafsir
}

\author{
Asep Mulyaden \\ UIN Sunan Gunung Djati \\ asepmulyaden@gmail.com
}

\section{Suggested Citation:}

Mulyaden, Asep. (2021). Ideologi Islam Tradisionalis dalam Tafsir. Jurnal Iman dan Spiritualitas, Volume 1, Nomor 2: pp 187197. http://dx.doi.org/10.15575/jis.v1i2.11898

\section{Article's History:}

Received 2021-03-03; Revised 2021-05-04; Accepted 2021-05-04.

2021. journal.uinsgd.ac.id @. All rights reserved.

\begin{abstract}
:
Indonesian Islam consists of various groups and organizations, including Traditional Islam or a group that combines Islamic teachings with local customs and Islamic customs throughout the world. This study aims to identify the interpretation of traditional Islamic ideology from relevant references. It used a qualitative method, collected primary and secondary data from the literature study, and explained them through the descriptive analysis method. The results showed that some of the Traditional Islamic Groups are members of the Nahdlatul Ulama organization and others. They have unique characteristics, including exclusive and not accept others' opinions outside the group. This group has a powerful network and spreads to remote areas through Pondok pesantren. The spread began with the entry of Islam to Indonesia in Sumatra, especially Aceh, and in Java through Wali Songo. Then, it produced great ulama who spread throughout the remote area and founded pesantren or Islamic boarding schools. They spread traditional Islamic teachings through oral and written in the pesantren. They published many written works in the religious field covering figh, Sufism, tasawuf, and tafsir. They had two learning methods, namely sorogan and bandungan. At first, in learning tafsir, they only used because as teachers and very simple pass it on. They thought that appreciating classic works is an appreciation of tradition. But after getting a lot of criticism from the reformists (modernists), they began to expand the teachings to various tafsir and wrote more about it. In writing tafsir, they often involve the traditionalist ideology based on Islam Aswaja (Ahlu Sunnah Waljamaah). They wrote about Aswaja's interests in the tafsir, especially as rebuttals to reformist groups, both in the fields of figh, tauhid, and tasawuf as contained in the tafsir of KH. Ahmad Sanusi.
\end{abstract}

Keywords: religious school, al-Qur'an interpretation, Indonesian Islam, modernization of religion

\begin{abstract}
Abstrak
Islam Indonesia terdiri dari berbagai golongan, kelompok dan organisasi. Diantara kelompok Islam Indonesia ada yang dinamakan Islam Tradisional. Yaitu, kelompok Islam yang mengkombinasikan ajaran Islam dengan kebiasaan, adat kedaerahan dan kebiasaan Islam di seluruh dunia. Dengan demikian penulis akan mencari tahu dari berbagai referensi yang terkait dengan ideology Islam Tradisionalis dalam tafsir. Penulis akan menelitinya dengan metode kualitatif, yaitu dengan menghimpun data kepustakaan sebagai data primer dan sekunder, lalu dijelaskan dengan metode deskriptif analisis agar tercapai tujuan penelitian. hasil penelitian yang dilakukan ternyata diketahui bahwa Kelompok Islam Tradisionalis sebagiannya ada yang tergabung dalam organisasi Nahdlatul Ulama dan ada juga di organisasi lainnya. Mereka memiliki cirri yang khas, yaitu bersifat eksklusif dan tidak menerima pendapat yang bersunber dari luar kelompoknya. Kelompok ini memiliki jaringan yang sangat kuat dan menyebar ke seluruh ploksok melalui pondok pesantren. Penyebaran mereka diawali dengan masuknya Islam ke Indonesia di Sumatra, terutama Aceh dan melalui penyebaran Islam di Jawa melalui Wali Songo. Dari situ lahir lah para ulama besar yang menyebar keseluruh plosok dan mendirikan pesantren. Di pesantren ini mereka menyebarkan ajaran Islam tradisionalis melalui lisan dan tulusan. Mereka banyak menerbitkan karya-karya tulis dibidang keagamaan, baik itu fikih, tasawuf, tauhid dan tafsir. Dalam metode belajar, mereka memiliki dua metode, yaitu sorogan dan bandungan. Dalam pembelajaran tafsir, pada awalnya mereka hanya menggunakan satu tafsir saja yaitu Tafsir Jalalain, karena tafsir ini merupakan tradisi yang diwariskan oleh guru-guru dan merupakan tafsir yang sangat simpel. Mereka beranggapan, bahwa mengapresiasi karya-karya ulama kelasik merupakan apresiasi terhadap tradisi. Namun setelah mendapatkan banyak kritikan dari kalangan reformis (modernis), mereka mulai memperluas ajaran mereka tentang tafsir, sampai mempelajari berbagai tafsir dan mereka lebih banyak lagi menulis tafsir. Dalam penulisan tafsir, meraka kerap kali membawa kepentingan ideology
\end{abstract}


tradisionalis yang berlandaskan Islam Aswaja (Ahlu Sunnah Waljamaah). Kepentingan-kepentingan Aswaja mereka tulis dalam tafsirnya, terutama sebagai bantahan terhadap kelompok reformis, baik bidang fikih, tauhid, maupun tasawuf. Hal ini seperti yang terdapat dalam tafsirtafsir karya KH. Ahmad Sanusi.

\section{Keywords: mazhab keagamaan, tafsir al-Qur'an, Islam Indonesia, modernisasi agama}

\section{PENDAHULUAN}

Islam di Indonesia merupakan Islamterbesar di dunia, itu yang sering kita dengar dari orang-orang terutama di media (Wibisono, 2020).Diantara kelompok Islam di Indonesia ada yang disebut Islam tradisionalis. Ide tentang paham tradisionalis buka merupakan hal baru. Di dunia Barat ide tersebut muncul pada abad ke-18 dan 19. Pada masa itu pengertian tradisi cenderung pada bentuk tertentu, seperti: mitos, legenda, cerita rakyat, hukum adat, sastra lisan dan ritual keagamaan (Rahman, 2016). Lain halnya dengan dunia Islam, di dunia Islam, ide tersebut telah ada bahkan sebelum masapra-Islam. Sebab seperti yang kita ketahui bahwa Nabi Muhammad saw. di utus dengan membawa syareat Islam yang beberapa elemennya merupakan tradisi umat terdahulu, seperti: ibadah shalat, puasa, haji dan banyak lagi ibadah yang lainnya (Zulaiha, 2017).

Namun ide tersebut barumengemuka sebagai gerakan sosial keagamaan pada abad ke-20. Kemunculan Islam Tradisionalis merupakan reaksi terhadap perubahan sosial akibat moderenitas yang cenderung melupakan tradisi (El Rahma, 2017). Islam tradisionalis yang dimaksudvdalam konteks ini menurut Zamakhsyari Dhofir, seperti dikutip oleh Iva Yulianti Umdatul Izzah, adalah muslim yang terikat dengan kuat oleh pikiran-pikiran ulama ahlifigh, hadits, tafsir, tauhid dan tasawuf yang berkembang abad 7 hingga abad 13 . Mereka berhasil menghimpun kekuatan yang besar selain karena pengikutnya yang banyak melebihi Islam modern juga karena kuatnya solidaritas dan integritas mereka (Izzah, 2011).

Kelompok ini memiliki berbagai ciri yang sangat melekat, seperti sifatnya yang eksklusif, menerima pemikiran atau pendapat yang berasal dari luar kelompoknya dan biasanya merupakan kelas menengah ke bawah. Bagi kelompok ini, berbagai aspek keagamaan, baik motodologi pengambilan hukum atau keputusan hukum harus mengikuti keputusan yang diambil oleh Nabi saw., Para sahabat dan ulama salaf al-salih. Sikap eksklusif mereka ditampilkan dengan orientasi keagamaan yang hanya melihat masa lampau, selain itu juga dipicu oleh basis pendukungnya yang tumbuh di pedesaan. Mereka dalam kelas menengah ke bawah yang berprofesi sebagai petani. Profesi tersebut otomatis membuat mereka tidak melakukan mobilisasi dan interaksi dengan dunia luar.

Menurut Wiliam S. Shephard, pekerjaa dikutip oleh Vicky Ezza El Rahma, Islam Tradisionalis merupakan kelompok yang kurang mampu membedakan antara hal yang bersifat ajaran dan yang bukan ajaran. Mereka menganggap semua tradisi yang diwariskan oleh Nabi saw., Para sahabat, serta para ulama salaf merupakan ajaran agama yang harus dipertahankan tanmpa kecuali. Dengan kata lain, kelompok agama mereka cenderung tekstualis (El Rahma, 2017).

Ideologi kelompok tersebut dapat kita lihat dari cara mereka dalam menafsirkan al-Qur'an. Setidaknya ideologimereka dapat dilihat dari tafsir Sunda karyaKH. Ahmad Sanusi (1888-1950). la menafsirkan al-Qur'an dengan menunjukanlatar belakang tradisionalis yang sangat kuat. la mewujudkan pemikirannya dalam tradisi intelektual berupa tafsir Sunda yang seolah-olah merupakan penyambung tradisibudaya pesantren yang ia wujudkan kedalam tafsir Sunda. Meski sosok sanusi dikenal controversial. Karena ia beranikonfrontatif terhadap Belanda dan juga empat adu argument dengan kalangan Islam Modernis seperti MASC, Persis dan kalangan tradisionalis lainnya (Rohmana, 2017)

\section{METODE}

Metode yang digunalkan dalam Penelitian ini adalah metode deskriptif, yaitu merupakan metode penelitian yang menginterpretasikan dan mendeskripsikan sesuatu, seperti kondisi atau hubungan yang ada, pendapat yang berkembang dan proses yang sedang berlangsung (Sukmadinata, 2019). Berdasarkan metode tersebut, maka dalam penelitian ini penulis akan berupaya mengungkapkan pemahaman para ahli yang telah melakukan penelitian dan telah memberikan pandangan terkait ideologi IsIm Tradisionalis yang dikemukakan dalam kitab tafsir, faktor penyebab masuknya ideologi tersebut ke dalam tafsir, dan proses tersebarnya pemahaman tersebut. Penelitian yang dilakukan ini diawali dengan menginpentarisir berbagai data yang berkaitan dengan tema penelitian. kemudian peneliti mempelajari dan menganalisis data tersebut, selanjutnya disusun secara sistematis dan logis.

\section{HASIL PENELITIAN DAN PEMBAHASAN}

\section{Kajian Tafsir Tradisionalis Dalam Kurikulum Pesantren}

Secara etimologi, tafsir berasal dari kata al-fash yang artinya, الايضاح الكشف. . Dalam Lisan al-'Arab, kata al-fasr artinya menyingkap sesuatu yang tertutup. Sedangkan kata al-tafsir artinya menyingkap suatu lafaz yang musykil. Adapaun secara terminologi, tafsir adalah:

$$
\text { علم يبحث عن القران الكريم من حيث دلالته على مراد الله تعلى بقدر الطاقة البشرية }
$$


"IImu yang membahas hal ihwal al- Qur'an dari segi dilalahnya berdasarkan maksud yang dikehendaki Allah swt. sesuai dengan kemampuan manusia".

Berdasarkan definisi di atas, tafsir berarti menjelaskan maksud Allah swt. dengan kemampuan manusia. Oleh sebab itu, maka kita sering mendapatkan perbedaan antara satu tafsir dengan tafsir yang lainnya. Hal ini dapat kita lihat pada tafsir Ibn 'Abbas dan Tafsir Jalalain dalam menafsirkan surat Ali' Imran ayat 7 kata ta'wilahu. Ibn 'Abas menafsirkan dengan 'Aqibat, sedangkan Jalalain menafsirkan dengan kata "tafsir".

Yang dimaksud dengan tradisional secara etimologi diambil dari kata tradisi, artinya menurut Kamus Besar Bahasa Indonesia adalah kebiasaan yang diturunkan dari nenek moyang yang dijalankan oleh masyarakat. Sedangkan tradisionalisme yaitu ajaran atau paham yang berdasarkan tradisi (Tim Prima Pena, 2012). Dilihat dari etimologi tradisi berarti sesuatu yang ditransmisikan dari generasi terdahulu kepada generasi berikutnya.

Sementara dalam terminologi, tradisi menurut Edward Shils, kalimat yang dikutip oleh Vicky Izza El Rahma, adalah sesuatu yang telah diciptakan, diatur dan diperaktekan pada masa lampau baik mengenai metode berpikir, karya-karya yang dihasilkan atau keyakinan yang ditransmisikan melalui tulisan atau tulisan, seperti keyakinan agama, sekular, keyakinan yang dihasilkan logika dan keyakinan yang diwahyukan Tuhan (El Rahma, 2017).

Adapun yang dimaksud dengan Islam tradisional adalah kelompok Islam Adat yang mengkombinasikan ajaran Islam dengan kebiasaan, adat kedaerahan dan kebiasaan yang dilakukan di seluruh dunia Islam (Huda, 2009). Ide tentang tradisionalis di Barat mulai muncul abad ke-18 dan 19. Sedangkan tradisionalis sebagai gerakan keagamaan baru muncul pada abad ke-20. Munculnya Islam tradisionalis merupakan reaksi dari perubahan sosial yang muncul akibat Islam Modernis yang cenderung melupakan tradisi (Akbar \& Rahmat, 2021). Islam tradisionalis memiliki cirri yang melekat yaitu sifatnya yang ekslusif, enggan menerima pemikiran, pendapat dan saran yang berasal dari luar kelompoknya. Mereka hanya menerima metodologi pengambilan hukum yang diambil oleh Nabi saw., para sahabat dan ulama salaf al-saleh.

Dalam konteks Indonesiaan, Nahdhatul Ulama (NU) merupakan organisasi kemasyarakatan yang berorientasi Islam tradisionalis (Rahman \& Mimbar, 2018). Orientasi ormas tersebut telah jelas terlihat dari faktor kelahirannya. Ditilik dari kacamata historis, 12 tahun sebelum didirikannya NU pada tahun 1926, merupakan masa-masa pergulatan antara gerakan tradisionalis-lokal dan gerakan purifikasi-global. Islam tradisionalis yang berakar pada institusi pesantren berhadapan dengan gerakan purifikasi-global yang digalakan oleh kelompok Wahabi di Arab Saudi (El Rahma, 2017).

Adapun yang dimaksud dengan pesantren adalah sekolah atau asrama yang menjadi tempat para santri menuntut ilmu agama (Tim Prima Pena, 2012). Mengacu pada tipologi pesantren yang ditawarkan oleh Kementrian Agama, pesantren terdiri dari tipologi, yaitu pesantren salaf, kombinasi dan modern (Afifulah, 2019). Pesantren tipe yang pertamalah yang merupakan pesantren kelompok Islam Tradisionalis. Materi pelajaran yang dikaji di pesantren-pesantren menurut L.W.C. Van den Berg, seperti yang dikutip oleh Rosihon Anwar dan kawan-kawan, adalah fikih, bahasa Arab, ushuluddin, tasawuf dan Tafsir. Namun menurutnya, tafsir yang dikaji di pesantren-pesantren hanya satu tafsir saja yaitu Tafsir Jalalayn. Memang ada juga yang mengkaji tafsir lain yaitu Tafsir al-Baidawi, namun sangat sulit menemukan kiai yang mengkaji tafsir tersebut (Anwar et al., 2016).

Menurut Kurdi Fadlal, para pengasuh pesantren yang belajar di Timur Tengah kemudian mengajarkan ilmunya kepada para santri, terutama bidang tafsir, dengan menggunakan dua metode. Pertama, menympaikan secara langsung dari kitab tafsir, sedangkan yang kedua, dengan cara membacakan kitab tafsir tertentu. Cara yang pertama disampaikannya ketika kiyai memberikan jawaban kepada para santri dan masyarakat dengan berupa fatwa. Fatwa tersebut mengacu atau bersandar pada al-Qur'an dan hadits karena mereka sangat menguasai keilmuan al-Qur'an. Sedangkan cara yang disampaikannya dengan cara bandungan dan sorogan. Metode ini merupakan tradisi kesinambungan yang dilakukan di pesantren-pesantren sejak abad sebelumnya (Fadlal, 2016).

Metode bandungan tidak lepas dari tradisi yang mereka lakukan di Timur Tengah, yang merupakan implikasi dari jaringan keilmuan pesantren Jawa dengan keilmuan Timur Tengah (Haramain). Mereka para tokoh pesantren memiliki sanad keilmuan, termasuk tafsir, dengan ulama Timur Tengah, baik secara langsung, yaitu dengan belajar di Timur Tengah maupun tidak langsung, yaitu dengan belajar kepada ulama yang pernah belajar di Timur Tengah (Batoro et al., 2013).

Sejak lama Tafsir Jalalain ini telah digunakan sebagai bahan pengajian di Tanah Haramain, setidaknya kitab ini dikaji di Tanah Suci sejak abad 16 Masehi. Sementara di Indonesia pengenalan al-Qur'an sudah dilakukan sejak lam. Mereka yang memperkenalkan al-Qur'an di Indonesia mendapatkan pengalaman pembelajaran di Mekah, disana mereka mengenal dan mempelajari Tafsir Jalalain. Sepulangnya ke tanah air, mereka memperkenalkan dan mengajarkan tafsir tersebut dengan tradisi yang mereka alami di Makah, sehingga kitab ini menjadi populer dan menjadi favorit bagi kalangan pesantren. Setidaknya tafsir ini diperkenalkan di Indonesia sejak abad 19 Masehi.

Menurut Yunus, seseorang dikutip oleh Kurdi Fadlal, bahwa tafsir ini merupakan bagian dari sisitem pendidikan yang dilakukan di surau- surau, disamping kitab-kitab keislaman yang lainnya. Mereka memilih tafsir ini karena penyampaiannya sangat ringkas dan mudah digunakan oleh pemula, popularitas tafsir ini yang dimulai hingga sekarang. Di berbagai pesantren yang ada di Jawa, kitab ini masih menjadi rujukan utama dalam menafsirkan al-Qur'an.

Namun dalam beberapa dekade terakhir, pesantren juga memperkenalkan tafsir lainnya sebagai bahan kajian dan kurikulum pesantren. Misalnya, di Pesantren Cipasung Jawa Barat, dijumpai pengkajian Tafsir Ayat al-Ahkam karya 'Ali alSabuni. Di pesantren lainnya, sperti Pesantren Dasussalam menggunakan Tafsir al- Munir, Tafsir Ibn Katsir dan Tafsir alMaragi (Fadlal, 2016). 
Menurut Salman Harun, dikutip oleh Afifullah, bahwa Tafsir Jalalayn diperkenalkan di nusantara dimulai sekitar abad ke17 oleh Abdurrauf al- Sinkeli melalui Tarjuman al- Mustafid yang menggunakan bahasa Melayu dan terbit di Istambul. Kurdi Fadlal mengungkapkan bahwa Tafsir Jalalayn merupakan kajian tafsir di Haramain sejak abad ke-16. Dan menurut Riddel, Abdurrauf al-Sinkili menghabiskan masa belajarnya di Haramain selama 20 tahun. la baru kembali ke Indonesia pada tahun 1661 M. Oleh sebab itu dapat dipastikan bahwa Abd al-Rauf mempelajari Tafsir Jalalain di Haramain dan belajar di Indonesia. Kurdi menambahkan, bahwa Tafsir Jalalayn dikenal dan disebar luaskan di Indonesia melalui jaringan keulamaan nusantara yang belajar di Haramain (Afifulah, 2019).

Menurut Martin Van Bruinessen (1995), mengutip Rosihon Anwar dan kawan-kawan, dampak dari maraknya gerakan Islam modernis yang selogannya "kembali kepada al-Qur'an dan Sunnah", banyak ulama tradisional yang mulai mengkaji tafsir secara lebih serius dengan memasukkan berbagai macam tafsir pada kurikulum pesantren, seperti Tafsir al-Tabar, Tafsir Ibn Kasir dan Tafsir al-Munīr. Namun Tafsir Jalalayn masih sebagai kitab yang sangat dominan. Tafsir tersebut dikaji di Pesantren Buntet Cirebon, Pesantren Cipasung Tasikmalaya, Pesantren al-Masturiayah Sukabumi dan berbagai pesantren lainnya.

Bahkan, di Pesantren al- Masturiyyah dan Pesantren Buntet hanya Tafsir Jalalain yang diajarkan kepada para santri. Namun di pesantren yang memiliki santri dari kalangan mahasiswa di pula tafsir yang lainnya seperti Tafsir Ahkam karya alSabuni, Tafsir al- Munir, Tafsir Ibn Kasir, Tafsir al- Maragi dan Tafsir Safwah al-Tafsir.

Di tiap pesantren yang ada di Jawa Barat, Tafsir Jalalayn dijadikan kajian pertama dan yang utama karena memiliki dua alasan. Pertama, terkait dengan keunggulan yang dimiliki Tafsir Jalalayn. Hampir seluruh pengasuh pesantren yang diwawancarai Rosihon Anwar mengatakan tafsir ini sangat ringkas, praktis, mudah dibaca dan paling cocok untuk pemula. Bahkan kelebihan yang paling menonjol dari tafsir tersebut adalah makna tekstualnya (Anwar et al., 2016).

Tafsir tersebut menggunakan pendekatan mufradat dan pengawasan keutuhan dan kemurnian bahasa (Zulaeha, 2020). Hal ini sangat penting bagi pemula pemula, mengingat untuk memahami al-Qur'an secara kontekstual, mereka harus terlebih dahulu terlebih dahulu memahami pemahaman tekstual al-Qur'an. Karena makna kontekstual beada setelah makna tekstual. Sedangkan tafsir modern yanag sangat banyak ragamnya merupakan pengembangan setelah memahami makna tekstual. Maka tidak heran jika para santri di pesantren terlebih dahulu menggunakan tafsir tersebut. Sedangkan untuk pengembanganya mereka mengmbil referensi tafsir yang lain.

Kedua, tafsir tersebut merupakan tafsir yang turun temurun. Di Pesantren Cipasung misalnya, tafsir tersebut sudah oleh pendirinya yang kemudian dikembangkan oleh Kiai llyas Ruhiat dan sekarang oleh para penerusnya (Adeng, 2014). Kiyai pesantren berpandangan bahwa pengapresiasian terhadap karya- karya ulama kelasik merupakan apresiasi terhadap tradisi. Hal ini senada dengan yang dikatakan oleh Masdar F. Masudi (1996), bagi masyarakat pesantren, ilmu adalah sesuatu yang hanya dapat diperoleh melalui jalan pengalihan, pewarisan, transmisi dan bukan sesuatu yang bisa diciptakan. Menurutnya, ada dua pertimbangan yang berkaitan dengan panadaangan tersebut. Pertama, keseragaman merupakan hal yang mudah sebagai cirri. Meskipun ada perbedaan maka perbedaan itu hanya dari aspek pengungkapan saja. Kedua, kitab yang merupakan karya ulama terdahulu memberikan keterngan langsung tentang wahyu yang bersifat sentral, sedangkan para kiyai hanya sebagai penyambung atau alat.

Dominasi Tafsir Jalalain di pesantren bukan berarti hanya kitab itu sja yang dikaji. Dominasi tersebut harus dilihat dalam konteks tafsir yang dikaji dan dibacakan secara resmi kepada para santri. Karena pada saat pengkajian, isi kitab-kitab tafsir lain pun mengajar, namun tidak merujuk pada sumber-sumbernya.

Rosihon dan kawan-kawan mengungkapkan, bahwa Mahmud Yunus telah menceritkan pengalaman belajar di pesantren. la menceritakan bahwa pada masa itu, yaitu awal abad ke 20, tidak semua santri peternakan pantas belajar tafsir, hanya santri senior saja yang diizinkan mempelajari tafsir. Tahapan para santri dalam belajar pada saat itu dimulai dari mempelajari kitab tingkat elemen, kemudian harus menamatka kitab tingkat menengah. Setelah tahapan itu dilaluinya, baru para santri belajar untuk mempelajari Tafsir Jalalayn.

Cara mereka mempelajari tafsir di pesantren terdiri dari tiga tahap, yaitu mula-mula sang kiai membaca Tafsir Jalalayn dalam bahasa Arab, kemudian ia menerjemahkannya kata perkata, setelah itu baru ia menerangkan maksudnya dengan bahasa Melayu atau bahasa daerah. Tugas santri dalam pelajaran ini hanya menyimak kitabnya masing-masing.

Cara belajaran yang mengasah Mahmud Yunus ternyata masih berlanjut sampai saat ini (Kodir, 2015). Rosihon dan kawan-kawan melakukan observasi di berbagai pesantren di Jaawa Barat, ternyata pesantren tersebut rata-rata masih menggunakan metode bandungan dan sorogan dalam belajar kitab tafsir. Bandungan yang dimaksud adalah kiai membaca dan menjelaskan kitab, dari mulai lugot kata perkata hingga menjelaskan maksudnya. Sedangkan para santri hanya mendengarkan dan menulis lugot dan penjelasan yang penting. Adapun kitab yang dimaksud dengan sorogan adalah belajar baca kuning dihadapan kiai, ada yang dibaca terlebih dahulu oleh kiai kemudian santri mengikutinya ada pula santri yang membaca dan kiyai yang mendengarkan.

Kedua metode tersebut masih digunakan oleh para kiai, karena pendekatan efektif dan sudah menjadi tradisi. Misalnya di pesantren al-Jawami, pola bandungan yang dipilih oleh kiyai sebagai metode pembelajaran, karena metode ini merupakan metode yang mengajar pleh pendiri pesantren terdahulu. Sementara di Pesantren al-Masthuriyyah, metode yang dipilih adalah sorogan, karena kiyai lebih mudah dalam membimbing, dan menilai kemampuan para santri dalam pembacaan kitab kuning. Pola ini digunakan di pesantren tersebut sejak berdirinya pesantren sampai sekarang. Dalam pola kelasik ini, kiyai berharap dapat meningkatkan intelektual dan sepiritual para santri. Di pesantren Darusalam pun menggunkan metode sorogan. Metode 
ini digunakan karena sudah teruji percayanya dan sudah menjadi tradisi pesantren. Alasan-alasan tersebut kurang lebih sama dengan lamaran oleh kiai-kiai pesantren lainnya.

Dalam metode bandungan, kiai membaca teks Tafsir Jalalain dihadapan para santri, kemudian ia menterjemahkannya kata perkata. Para santri mengikuti apa yang dibayar oleh kiai dan mereka mencatatnya di bawah kata yang digunakan. Setelah itu kemudian kiai menjelaskan maksudnya dengan bahasa Indonesia atau bahasa Sunda, setelah dirasa cukup kemudian kiai menutup pengajian tanpa sesi tanya jawab.

Dalam sisitem sorogan, kiai membaca teks tafsir terlebih dahulu dihadapan beberapa sntri saja, kemudian ia menerjemahkannya kata perkata, sesudah itu lalu ia meminta santri untuk mengulangi apa yang ia ajarkan, selanjutnya kiai menjelaskan maksud dari teks tersebut dengan bahasa Indonesia atau bahas Sunda. Jika waktu belajar telah habis lalu kiai menutup pengajian tampa adanya Tanya jawab. Kalau pun ada kiai yang mempersilahkan untuk bertanya maka para santri enggan uantuk bertanya, karena mereka sudah lelah, karena malu atau karena bertanya kepada guru jawaban tidak sopan. Tidak bertanya kepada guru merupakan akhlak mulia mengajar dalam kitab Ta'li m al-Muta'allim.

Ketidak mauan para santri untuk brtanya pada kiyai juga didukung oleh situasi dan situasi. Metode bandungan dan sorogan yang diterapkan di pesantren diawali dengan penataan ruang yang membentuk formasi duduk para santri. Biasanya kiyai duduk di atas kursi yang dilandasi bantal, sedangkan para santri duduk di kiyai. Menurut Nurcholis Majid, sperti dikutip oleh Rosihon, filosofi duduk ini bertujuan agar para santri hormat dan sopan ketika mendengarkan apa yang disampaikan kiyai.

Metode sorogan dan bandungan ini, memang memiliki kelemahan. Menurut Amakhsyari Dhofier, seperti dikutip oleh Rosihon, banyak santri di pedesaan yang gagal dalam pendidikan yang menggunakan metode tersebut, karena metode tersebut dipandang paling sulit dari seluruh sistem pendidikan tradisional. Sebab metode tersebut membutuhkan kesabaran, ketaatan, kerajinan dan disiplin pribadi santri. Kekurangan tersebut, para kiyai meyakini keefektifan metode itu dalam mencapai tujuan pendidikan di pesantren. Selain itu juga dikenal dengan istilah barokah, yaitu nilai-nilai ilahiyyah yang akan didapatkan melalui para santri. Istilah ini biasanya bersanding dengan istilah futuh, yaitu, yaitu dari Allah swt dalam menuntut ilmu. Kedua istilah ini dikenal dengan ilmu laduni (Anwar et al., 2016).

Memang komunitas santri memiliki sistem dan nilai yang berbeda dengan sistem manapun. Sistem tersebut mempunyai cirri dan watak terpisah, yang menurut Abdurrahman Wahid disebut "subkultural". Nilai pokok yang berkembang dalam komunitas santri adalah bahwa kehidupan ini seluruhnya merupakan ibadah. Seorang santri sejak memasuki komunitas ini telah diperkenalkan dengan nilai tersebut. Nilai yang demikian ini bersifat dinamis, tidak hanya penyerahan kepada Allah swt. saja, namun aktivitas formal yang berkaitan dengan materi pun harus bernilai ilahiyyah (Wahid et al., 1998).

Ketaan santri terhadap kiyai merupakan manifestasi ketaatan mutlak yang dipandang sebagai ibadah. Kecintaan terhadap ilmu pengetahuan dan agama yang sangat kuat merupakan landasan untuk memahami kehidupan yang semuanya merupakan ibadah. Kecintaan tersebut kemudian dibuktikan dengan berbagai bentuk, penghargaan kepada para ulama, ahli ilmu agama, kesediaan utnuk berkorban, kerjakeras dalam mencari ilmu, dan kesediaan untuk mengembangkan ilmu dalam lembaga yang sama-sama tampa memperdulikan setiap rintangan dan hambatan yang berhubungan. Kecintaan tersebut juga dibuktikan dengan kesediaan mengaji kepada kiyai dengan waktu yang lama dan ketekunan dalam mengkaji tingkatan ilmu.

Selain nilai cinta ilmu dan serba ibadah, ada nilai lain yang memang mempengaruhi kehidupan santri, yaitu keikhlasan dalam melaksanakan semua yang diperintahkan oleh kiyai tanpa sungkan dan berat. Begitu pun pengabdian kiai dalam organisasi lembaganya tanpa memperhatikan pribadi merupakan keiklasan timbal balik antara santri dengan kiyai. Rangkuman nilai tersebutlah yang membentuk watak dunia pesantren, memandang sesuatu secara materi, materi hanya bagian dari nilainilai ilahiyyah, yang kemudian dilaksanakan dengan ketekunan dan kerelaan.

Menurut Zamakhsyari Dhofier, sperti yang dikutip oleh Iva Yulianti, kiyai merupakan gelar ahli agama Islam yang menjadi pemimpin pesantren dan mengajar kitab-kitab klasik kepada para santri. Kalau di Jawa Barat gelar itu disebut Ajengan. Sedangkan di Jawa Tengah dan Jawa Timur disebut kiyai. Dengan pengetahuan tentang agama Islam, kiai dilihat sebagai orang yang senantiasa dapat memahami keagungan Tuhan dan rahasia alam, dengan demikian mereka memiliki tempat yang tinggi yang tidak terjangkau oleh kebanykan orang, terutama oleh orang awam. Dalam beberapa hal mereka memiliki kehususan, terutama dalam bentuk pakaian yang menjadi simbol kealiman, yaitu dengan menggunakan kopiah dan surban.

Menurut Martin Van Bruinessen, seperti yang dikutip oleh Iva Yulianti, kiyai lebih dari sekedar guru. la merupakan pembimbing spiritual bagi mereka yang taat dan pemberi nasehat dalam masalah kehidupan, pemimpin ritual penting dan pembaca do'a dalam ritual penting. Tidak sedikit kiyai Jawa yang tidak memiliki kesaktian tertentu yang dapat mengusir roh jahat, menymebuhkan penyakit, membuat jimat, dan melatih teknik tubuh. Walaupun mereka tinggal di pedesaan tetapi mereka merupakan kelompok elit dalam struktur sosial, politik, dan ekonomi masyarakat di Jawa. Suatu kelompok yang memiliki pengaruh penting di Jawa, kiyai merupakan kekuatan penting dalam politik Indonesia (Izzah, 2011).

\section{Jaringan Mufassir Tradisionalis di Indonesia}

Ada dua teori yang terkait masuknya Islam ke Indonesia, yaitu Teori Timur dan Teori Barat. Menurut teori Timur, masuknya Islam ke Indonesia pada abad VII M. atau abad I H., yang disebarkan oleh para pedagang Arab yang bermazhab Syafi'i di daerah pantai utara Sumatra (Malaka). Sedangkan menurut teori Barat, masuknya Islam ke Indonesia pada abad XIII M. Teori ini bersumber dari perjalanan Marcopolo tahun $1292 \mathrm{M}$. dan didukung dengan catatan Ibn Bathuthah yang menjelaskan berdirinya kerajaan Islam di pantai utara Sumatra pada abab XIII M (Syafrizal, 2015). 
Berdasarkan teori Barat tersebut, yaitu masuknya Islam pertama kali di Aceh pada tahun 1290 M., maka pada saat itu Islam mulai lahir dan tumbuh, terutama setelah berdirinya kerajaan Pasai. Pada waktu itu banyak ulama yang merancang surau-surah, dan puncaknya kemajuan surau-surau pada jaman Iskandar Muda Mahkota Alam Sultan Aceh. Pada saat itu muncul ulam-ulama terkenal seperti Hamzah Fansuri, Nuruddin al-Raniri, Syamsuddin al-Sumatrani, Ahmad Khatib Langin, Burhanuddin dan Abd. Rauf al-Sinkili. Pada saat para ulama mengajarkan al-Qur'an di tempat-tempat tersebut.

Pada saat itu mempersiapkan al-Qur'an lebih kepada anak-anak berusia 6 sampai 10 tahun, yaitu mereka yang belum mencapai usia dewasa. Pembelajaran ini disampaikan di rumah guru, langgar atau surau. Namun sebagian ada juga yang dilaksanakan di rumah orang tua murid, terutama orang tua yang memiliki kedudukan penting. Pengajaran ini pada umumnya disampaikan oleh guru-laki, namun terkadang ada perempuan yang bisa mengaji dan mengajar al-Qur'an pada anak-anak di masyarakat. Sedangkan pembelajaran al-Qur'an orang dewasa atau usia dilakukan secara bersama-sama atau individu di tempat-tempat ibadah. Tujuan pembelajaran al-Qur'an untuk menciptakan sampai sekarang tidak lain untuk mematangkan agama, terutama tentang ketauhidan.

Sejak menyebarnya Islam di Nusantara yang dimulai dari Sumatra, terutama di Aceh, pembelajaran al-Qur'an tampak meyakinkan. Merujuk pada naskah-naskah yang ditulis oleh ulama asal Aceh, dapat diketahui bahwa pada abad 16 upaya penafsiran al-Qur'an dimulai. Hal ini dapat dilihat dari Tafsir surat al-Kahfi, yang tidak diketahui penulisnya, yang diduga ditulis oleh ulama Aceh pada awal pemerintahan sultan Iskandar Muda (1607-1636), dimana mufti kesultanannya adalah Syamsuddin al-Sumatrani, ataua masa sebelum itu, yaitu pada masa Sultan 'Ala al-Din Ri'ayat Syah Sayyid al-Mukammil (1537-1604), yang mana mufti kesultanannya adalah Hamzah al-Fansuri. Kemudian di wilayah Sumatra lainnya, muncul tafsir lengkap 30 juz yang ditulis oleh Abd. Rauf al-Sinkili (1615-1693). Tafsir ini berkembang bukan hanya di Indonesia melainkan di Negara Islam lainnya, seperti di Singapura, Penang, Bombay, Istanbul, Kairo dan Mekah.

Dari sini lah membangun al-Qur'an yang terkenal bahkan sampai kepada sufi di tanah air. Ketika mereka mengajarkan ajaran sufisme, tidak pernah mereka mengajarkan al-Qur'an. Hamzah Fansuri dan Syamsuddin Sumatrani misalnya, mereka menyampaikan al-Qur'an dengan pemahaman sufisme. Bahakan ada riwayat kecil yang menyampaikan bahwa masa kedua tokoh sufi tersebut telah menghasilakan tafsir kecil yang sangat sederhana, yaitu tafsir surat al-Kahfi yang diharuskan mengikuti tafsir al-Khazin.

Beberapa ahli yang mengkaji tafsir ini memberikan hasil pendapat yang besar. Pertama, Snouck Hurgronje menganggap bahwa terjemahan tersebut lebih mirip sebagai terjemahan Tafsir al-Baidawi. Rinks, yang merupakan murid Hurgronje, menambahkan bahwa tafsir tersebut merupakan terjemahan dari Taafsir Jalalain. Sedangkan Voorhove, yang sama sebagai murid Hurgronje, berpendapat bahwa tafsir tersebut mengambil sumber dari berbgai tafsir yang berbahasa Arab. Kedua, Riddel dan Harun, mereka mengatakan bahwa tafsir tersebut merupakan terjemahan dari Tafsir Jalalain. Hanya saja pada bagian tertentu tafsir tersebut mengambil sumber dari Tafsir al-Khazin dan Tafsir al-Baidawi (Tamam, 2018).

Sedangkan di daerah Jawa, Islam disebar luaskan oleh Wali Songo. Dalam penyebaran Isalam yang dilakukan oleh Wali Songo pun tidak lepas dari pembelajaran al-Qur'an yang dimulai oleh Raden Rahmat (Sunan Ampel). la mengajarkan alQur'an di pesantrennya di daerah Ampel. Proses pengolahannya tidak beda dengan aman di Sumatra, yaitu di surau, mushola, langgar, masjid, dan di rumah-rumah guru ngaji. Sejak proses Islamisasi yang dilakukan oleh Wali Songo dan berdirinya kerajaan Demak, sekitar tahun 1500 M., ternyata al-Qur'an semakin marak hanya dilakukan dengan sangat sederhana. Pada generasi berikutnya, kerajaan Islam dikuasai oleh kesultanan Mataran Islam. Terlihat dalam beberapa suluk, seperti Suluk Sunan Bonang, Suluk Sunan Kalijaga, dan Suluk Syaikh Siti Jenar, bahwa teks al- Qur'an merupakan rujukan yang sangaat penting dalam membangun konsepsi keagamaan (Ukhriyati, 2017).

Pada abad berikutnya, pengajaran al-Qur'an di tanah Jawa semakin marak. Pada tahun 1847, pengajaran al-Qur'an berlangsung di tempat yang disebut enggon ngaji. Namun pengajiandi tempat tersebut tidak sama jenjangny. Jenjang yang paling dasar diberikan pada anak usia 5 tahunan, yang mana pengajiannya di rumah orang tua yang peduli terhadap pengajian anaknya. Pada jenjang ini, anak-anak dibebani hafalan surat-surat yang pendek. Kemudian setelah merekamenginjak usia 7 sampai 8 mulai diperkenalkan dengan cara membaca huruf Arab sampai mampu menghafal al-Qur'an. Munculnya berbagai pesantren di wilayah Jawa secara meyakinkan danlembaga pendidikan sistem klasikal, menandakan pengajaran al-Qur'an semakin mendapatkan tempat yang strategis. Di daerah Jawa lahir pesantren-pesantren yang mengajarkan al-Qur'an mulai dari kaidah-kaidah tajwid sampai kandungannya (tafsirnya) (Atabik, 2014).

Ajaran keislaman yang ditanamkan di pesantren melalui tradisi yang dibangun oleh karya ilmiyah Islam. Sastra keislaman yang mengajar di pesantren tidak lepas dari jaringan ulama yang ada di Indonesia. Mereka memiliki jaringan tekstual dan intelektual yang serupa dengan tradisi yang berkembang di Mekah, yaitu tempat mereka menimba ilmu keislaman. Mereka menimba ilmu dari ulama yang bermazhab Ahlussunnah. Corak keislaman seperti ini mereka bawa ke Indonesia kemudian mengajar kepada santri dan warga yang ada di lingkingan pesantren (Azra, 2019).

Perkembangan jaringan Islam Tradisionalis terdiri dari tiga fase, dimana fase pertama dimulai pada abad 13 sampai abad 15 , fase kedua pada abad 16 sampai abad 18, dan fase ketiga dimulai pada abad 19 sampai abad 20 . Fase pertama disebut dengan fase embrio, karena pada fase ini keilmuan keislaman masih sangat sederhana. Pesantren saat itu baru menjadi pusat menjadi pusat islamisasi atau penyebaran agama Islam. Pada saat itu, Islam baru dikenal pada komunitas kecil saja dan baru dikenalkan pada masyarakat yang masih menganut agama nenek moyang.

Menurut Nasaruddin Baidan, seperti dikutip oleh Kurdi Fadlal, para Wali Songo yang menjadi plopor penyebar Islam saat itu baru memperkenalkan al-Qur'an dengan metode yang mudah diimplementasikan oleh masyarakat. Misalnya, Sunan Ampel 
pernah mengajarkan molimo, artinya tidak boleh melakukan lima perkara: (1) emoh main (tidak maumain judi); (2) emoh ngombe (tidak mau minum-minuman keras; (3) emoh madat (tidak mau ngisep candu atau ganja); (4) emoh maling (tidak mau mencuri); (5) emoh madon (tidak mau main perempuan atau berzina. Kemudian Sunan Ampel menyampaikan kepada muridnya, bahwa hal itu merupakan kandungan al- Qur'an (Ari, 2019).

Sedangkan fase kedua merupakan fase pemesanan. Karena pada fase ini masyarakat sudah mulai mengenal karyakarya ilmu keislaman, meskipun hanya dalam jumlah yang sangat sedikit. Pada tahap ini sudah mulai memperkenalkan kitab tafsir kepada masyarakat. Kitab tafsir yang pertama dibawa oleh para ulama adalah Tafsir Jalalain. Pada tahap ini al-Qur'an disampaikan dengan metode al-ra'yu, padahal di Timur tengah sedang marak menyampaikan dengan metode al-ma'tsur, seperti Tafsir al-Tabari dan Ibnu Katsir. Tokoh yang paling populer dalam fase ini adalah Abdur Rauf Singkel (1615-1693).

Sementara fase ketiga merupakan fase peneguhan intelektualisme di dunia pesantren. Fase ini diiringi dengan lahirnya ulama Nusantara yang belajar di Timur Tengan. Setelah kembali ke tanah air lalu mereka terbang ilmunya melalui pesantren yang mereka dirikan. Lambat laun mereka mampu menulis tafsir yang terkenal di pesantren-pesantren yang ada di Nusantara bahkan sampai dunia. Misalnya Syekh Nawawi al-Bantani dengan Tafsir Munir atau Marah Labid, Syekh Mahfudh al-Tirmisi dengan kitab Kifayah al-Mustafid fima 'Ala min al-Asanid, Thulatiyah al-Bukhari, dan lain-lain, Syekh Abdul Hamid Kudus dengan kitab Lathaif al -lsyarat dalam bidang Ushul Fiqh dan lainnya (Fadal, 2018).

Dari para ulama tersebut, keilmuan dan tradisi pesantren terbentuk berkembang hingga. Keilmuan yang paling nampak di pesantren yang mereka kembangkan adalah fikh, teologi dan tasawuf. Kemudian tradisi tersebut lambat laun membentuk sebuah ideologi yang khas di dunia pesantren. Ideologi Khas yang ada di pesantren tidak lepas dari para ulama yang memperkenalkan karya-karya keislaman, baik yang dikarang oleh mereka sendiri maupun yang mereka bawa dari Timur Tengah. Dalam bidang fikih yang paling dominan adalah mazhab Syafi'i. Karena mazhab ini yang mempelajari mereka ketika belajar ti Timur Tengah. Inilah latar belakang tradisi bermazhab yang ada di dunia pesantren.

Tradisi keilmuan pesantren di atas, membuktikan bahwa sejak awal mazhab pemikiran pesantren menganut paham Ahlussunnah wa al-Jama'ah. Mazhab ini kemudian berkembang semakin kuat di Indonesia melalui jaringan pesantren, khususnya di tanah Jawa. Konteks sejarah ini yang menjadi titik lahirnya organisasi Nahdhatul Ulama yang terkenal melalui jaringan pesantren. Melalui jalur NU ini lah ideologi Aswaja Sphere dengan rumusan Qanun Asasi yagn dibentuk oleh para pendiri NU. Pada awalnya dalam Qanun Asasi tidak ada penjelasan tentang definisi Aswaja, yang dijelaaskan hanya baru yang bersifat umum. Namun urayan lengkap baru dijabarkan melalui stidi yang bernama Tashwirul Afkar yang diketuai oleh Kiyai Wahab Chasbullah (w. 1971). Kemudian Aswaja didefinisikan oleh Kiyai Bisri Musthofa (w. 1977) yang berasal dari Rembang. Itu bahwa dalam bidang fikh harus mengacu pada madzhab yang empat yaitu: Malikiyah, Hanafiyah, Syafi'iyah dan Hanabilah. Sementara dalam bidang teologi mengacu pada paham Abu Hasan al-'Asy'ari (w. 324 H./935 M.) dan Abu Mansur al- Maturidi (w. 333 H./944 M.). Adapun dibidang tasawuf mengacu pada ajaran Abu Hamid al-Gazali (w. 505 H./111 M.) dan Junaidin al-Baghdadi. Pedoman definisi Aswaja tersebut dapat dilihat dalam kitab al-Kawakib al-Lama'ah karya Abul Fadhol dari Senori Tuban Jawa Timur yang ditetapkan secara formal dalam Muktamar ke-23 yang diselenggarakan di Solo pada tahun 1962 (Mufid, 2013).

Dari uraian tersebut dapat kita ketahui bahwa tidak tampak tradisi mengacu langsung kepada al-Qur'an dan Sunnah dalam lingkungan Islam Tradisional (Fadlal, 2016). Secara singkatnya, jaringan Islam Tradisionalis diawali dengan masuknya Islam ke Aceh dan melahirkan Hamzah Fansuri, Nuruddin al-Raniri, Syamsuddin al-Sumatrani, Ahmad Khatib Langin, Burhanuddin dan Abd. Rauf al-Sinkili. Abd. Rauf al-Sinkili dengan karyanya Turzuman al- Mustafidin, kemudian dilanjutkan oleh Munawar Chalid dengan Tafsir al-Qur'an Hidayah al-Rhman, yang kemudian dijanjutkan oleh ulama yang lainnya (Atabik, 2014).

Sementara di pulau Jawa diawali dari Wali Songo yang kemudian lahir Syekh Nawawi al-Bantani, Syekh Mahfud alTirmisi, Kiai Hasyim'Asy'ari, Syeh Abdul Hamid Kudus, Kiai Bisri Musthofa (Fadlal, 2016). dan banyak lagi ulama yang lainnya, misalnya di Jawa Barat ada Haji Hasan Mustafa Garut, Mama Gudang Tasikmalaya, Mama Syatibi Cianjur, Mama Tubagus Bakri Sempur, KH. Ahmad Sanusi Sukabumi,KH. Muhamad Ilyas Ruhiat Cipasung, Mama Choer Afandi Manonjaya, Sahibulwafa Tajul'arifin (Embah Anom) Suryalaya, dan masih abnyak lagi ulama yang lainnya.

\section{Respon Mufassir Tradisionalis Terhadap kritik Kaum Reformis}

Ajaran keislaman di pesantren ditnamkan melalui tradisi telah dan dikirim karya ilmiah Islam. Mereka mempelajari berbagai bidang keislaman seperti tasawuf, fikih, kalam, sastra dan tafsir, sehingga membentuk konstruksi ideologi mereka. Ideologi yang dimaksud adalah cara pandang secara umum yang ditulis dalam berbagai literatur oleh ulama pesantren. Ideologi tafsir pesantren berarti kecenderungan pemikiran yang populer dalam tafsir pesantren. Ideologi tafsir pesantren lebih bernuansa fikih dan tasawuf, hal ini diperoleh oleh faktor internal dan eksternal. Faktor internal yang dimaksud adalah faktor yang mempengaruhi pengarang dalam menafsirkan al-Qur'an, sedangkan faktor eksternalnya adalah fsktor luar yang mempengaruhi corak penafsirannya (Ari, 2019).

Dalam pembahasannya, tafsir yang lahir dari pondok pesantren sangat kental dengan corak fikih. Lahirnya corak tersebut merupakan respon dari jawaban terhadap masalah-masalah yang muncul di masyarakat. Sedangkan fikih merupakan ilmu yang membahas masalah kehidupan sosial beragama, baik yang berhubungan ibadah, muamalah, pernikahan dan yang lainnya. Oleh sebab itu, sangat wajar jika tafsir yang lahir dari kalangan ulama pesantren banyak menyinggung tentang hukum Islam yang merupakan kebutuhan masyarakat. Dapat kita lihat dalam Tafsir al-Ibriz, yang ditulis oleh Kiyai Bisri Musthafa, 
selain tasawuf di dalamnya memuat memuat seputar fikih. Demikian pula dengan tafsir pesantren yang lainnya, sperti Tafsir al-Iklil karya Kiyai Misbah Mustafa, Tafsir Faid al-Rhman fi Tarjamah Kalam Malik al-Dayyan karya Syaikh Muhammad Shaleh Ibn 'Umar al-Samarani yang dikenal dengan Kiyai Saleh Darat (1820-1903) ), dan Raudat al-'Irfan fi Ma'rifah al-Qur'an karya Ahmad Sanusi (1888-1950) (Fadlal, 2016).

Dalam hal ini, kita dapat melihat pada tafsir yang ditulis oleh Sanusi. la menafsirkan al-Qur'an dengan tema yang bermuatan ideologi tradisionalis. Penafsiran tersebut dapat dilihat dari faktor internal dan eksternal. Faktor internalnya Sanusi merupakan ulama yang berideologi Aswaja, yang tentunya memiliki kecenderungan penafsirannya pada Aswaja. Sedangkan faktor eksternal tafsir yang ditulis oleh Sanusi adalah tanggapan terhadap kritik yang dilontarkan oleh kelompok reformis.

Jajang A. Rohmana mengungkapkan, bahwa kelompok reformasi Islam merupakan kelompok yang pertamakali berubah kehidupan keagamaan di Indonesia. Pada mulanya kehidupan keagamaan Indonesia bagaikan air kolam yang tenang, namun pada awal abad ke-20 kehidupan tersebut berubah bagaikan air sungai yang sewaktu- waktu dapat meluap. Hal ini dilakukan oleh gerakan kelompok reformis yang berkeinginan untuk kembali kepa al-Qur'an dan Sunnah dalam kebenaran agama dan budaya masyarakat.

Munculnya kajian tentang ushulfuru' dan ijtihad beriringan dengan proses moderenisasi. Reformasi kelompk yang agresif mengkritik pemahaman Islam Tradisionalis yang sudah menyebar di kalangan masyarakat. Idealnya dibangun oleh pemikiran pembaharu yang lahir dari Mesir sekitar abad 20 meskipun proses pembaharuan itu tidak dapat dikaatakan sebagai pengulangan dari apa yang terjadi di Mesir, karena Islam di Indonesia merupakan Islam yang berbeda dengan Islam yang ada di Mesir. Islam Indonesia memiliki berbagai kompleksitas yang berbeda dengan Mesir, terutama Islam Indonesia memiliki kelenturan Islam pribumi, peran klonial Belanda dan kebijakan politik setelah kemerdekaan.

Beberapa ulama reformis, seperti lamaran Sanusi yang dikutip oleh Jajang A Rahman, melakukan gugatan terhadap berbagai tradisi Islam yang berkembang di masyarakat. Diantaranya Ajengan Anwar Sanusi dari Pesantren Biru Tarogong Garut, KH. Yusuf Taujiri dari Pesantren Cipari, KH. Muhammad Ba'li (Muhammad Zakaria), KH. Muhammad Romli dari Pesantren Haurkoneng, mereka tergabung dalam Majlis Ahlus Sunnah Cilame (MASC). Sedangkan dari kelompok Persatuan Islam diwakili oleh A. Hasan. la ulama yang sangat agresif melakukan debat dan publikasi pada kelompok yang pendekatan menyimpang seperti kaum tradisionalis.

Disatu sisi, Islam tradisionalis dituduh sebagai Islam penjaga sinkretik yang sangat menjamur di pulau Jawa yang merupakan basis pesantren. Hal ini dapat dilaksanakan, mengingat pola perkembangan Islam mengalami perubahan sejak akhir abad ke-17, yang semula berkemabang di daerah pesisir yang bersifat urban, dinamis dan agresif, kini nergeser ke daerah pedlaman yang berbasis pesantren dan menjadi tanda kejayaan Islam sinkretis yang tidak murni. Karena Islam bekerja dalam sistem budaya tradisional.

Oleh karena itu, peran kebudyaan pesantren berkonsentrasi terhadap pelestarian tradisi budaya lokal yang diinkulturisasikan kedalam ajaran Islam Aswaja. Islam ini mengacu pada teologi 'Asy'ari, fikih Syafi'i dan tasawuf Gazali. Mereka juga mengembangkan melalui khazanah kitab kuning yang disebut "memperdalam agama". Oleh sebab itu, Abdrrahman Wahid memposisikan pesantren sebagai subkultur terpisah, mengingat pesartren memiliki keunikan yang berbeda bila dibandingkan dengan yang ada di luar pesantren (Rohmana, 2017).

Tradisi keilmuan pesantren, baik fikih, teologi maupun tasawuf merupakan diskursus yang membentuk ideologi yang khas di dunia pesantren. Tradisi tersebut membuktikan bahwa sejak awal, mazhab pemikiran Islam pesantren mengacu pada mazhab Ahlus Sunnah Wal Jamaah (Aswaja) (Fadlal, 2016). Oleh sebab itu, tentu Sanusi pun menjawab gugata klompok reformis melalui tafsir yang berlandaskan Aswaja.

Menurut Jajang A. Rohmana, seluruh jejak ideologi Aswaja atau Islam tradisionalis setidaknya dapat dilihat dalam Tafsir Sunda karya KH. Ahmad Sanusi (1888-1950). la merupakan penyambung tradisi budaya pesantren yang ia wujudkan kedalam tafsir Sunda. Penafsirannya menunjukan latar belakang Islam Tradisional pesantren. Meski demikian, Sanusi sempat dikenal sebagai orang yang kontroversi, karena ia merupakan ulama yang konfrontatif terhadap kolonial Belanda dan sempat adu argumentasi dengan Islam Modernis seperti MASC dan Persatuan Islam. Sebagaimana ulama lainnya, Sanusi berusaha mempertahankan pemikiran tradisionalis melalui cara-cara yang modern. Namun yang perlu digaris bawahi, Sanusi bukan merupakan warga NU, karena ia memilih organisasi itu sendiri yaitu Alittihadiyatul Islamiyyah (All) pada tahun 1931. Namun ia memproklamirkan sebagai pembela Islam Aswaja, hal ini dapat dilihat dari karya-karyanya yang dapat digunakan untuk Islam tersebut dan mengecam kelompok Islam Modernis. Bahkan ia memberikan ciri-ciri Islam Aswaja, yang salah satunya dalah menyapu wajah setelah selesai shalat.

Tafsir Raudat al-'Irfan dan Tafsir Malja al-Talibin yang ditulis Sanusi, merupakan bagian dari penyambung kepentingan Islam Tradisionalis pesantren, ia merupakan transmisi lisan yang disampaikannya setelah ia kembali dari pengasingannya di Baavia. Tafsir ini ditulis oleh 30 santri Sanusi, kemudian disalin ulang oleh penulis (katib) yang menjadi kepercayaan Sanusi. Kemudian setelah disetujui oleh Sanusi, tafsir tersebut dicetk melalui cetkan batu (litografi) yang terletak di Pesantren Gunung Puyuh Sukabumi. Sementara Tafsir Malja al-Talibin merupakan tafsir pertama yang ditulis oleh Sanusi dengan menggunakan Bahasa Sunda. Bahkan Tafsir Raudat al-'Irfan pun, oleh taafsir ini. Proses pertapaan tersebut berlangsung ketika Sanusi berada di pengasingan, yaitu di Batavia. Edisi pertama tafsir ini dipublikasikan di sekitar Priangan, Banten, Batavia dan Purwakarta pada 28 Januari 1931. Jumlah tafsir ini sebanyak 28 jilid, 20 jilidnya terbit di Batavia dan sisanya terbit di Sukabumi. Dalam menafsirkan ayat tertentu, kerapkali muncul kepentingan Islam tradisionalis. Misalnya dalam menafsirkan teologi, fikih 
dan tasawuf. Dalam masalah fikih, kepentingan ideologi Aswaja dapat dilihat misalnya dalam Tafsir Raudat al-'Irfan dan Malja' al-Talibin ketika menafsirkan QS. Al-Ftihah ayat 1-7:

"Ceuk mazhab Syafi'i, Maliki, Hambali, jeung jumhur ulama wajib maca fatihah dina shalat henteu cukup ku anu sejen. Hujah riwayat Bukhari Muslim tina hadis Ubadah bin al-Samit. Kadua, hadis Abu Hurairah." (Rohmana, 2017).

Dari kutipan di atas dapat diketahui bahwa Sanusi definisi dan mengikuti pemahaman fikih yang menjadi rujukan Aswaja, yaitu madzhab fikih yang empat. Menurutnya, membaca surat al-Fatihah ketika shalat hukumnya wajib, berdasarkan pendapat Syafi'i, Maliki, Hambali dan Jumhur Ulama. Kewajiban membaca Fatihah ini tidak dapat menyimpan oleh bacaan yang lainnya. Even in Tafsir Malja al-Ta libin mengungkapkan berbagai hadis yang menunjukan wajibnya membaca Fatihah dalam shalat. Hadis itu menunjukan dengan sangat jelas bahwa membaca Fatihah diwajibkan bagi imam dan makmu disetiap rakaat shalat, baik nyarung maupun pelan-pelan. Jika imam membaca fatihah dengan cara nyaring, maka makmum wajib mendengarkan bacaan imam, setelah imam selesai membacanya maka makmum wajib membacanya secara pelan-pelan. Menurut Sanusi, hanya mazhab Hanafi yang membolehkan bacaan fatihah oleh bacaan lainnya (Rohmana, 2017).

Ideologi Islam tradisionalis memang menganut paham Aswaja yang rujukan fikihnya adalah mazhab empat (Hanfi, Maliki, Syafi'i, dan Hambali). Dalam bidang teologi mengikuti madzhab Abu Hasan al- 'As'ari dan Abu Mansur al-Maturidi, sedangkan dalam bidang tasawuf mengikuti Abu Hamid al-Gazali (Fadlal, 2016). Tafsir lain yang dimunculkan oleh Sanusi mengenai ideologi terkait Aswaja adalah tawassul, lamaran yang dilalui oleh Jajang A. Rohmana. Tawassul adalah ritual membaca doa yang biasa dilakukan oleh orang Sunda pada saat ziarah kubur dan ritual lainnya. Di jawa tawassul erat bergantungnya dengan ziarah, nyekar dan sowan. Peraktek ini umumnya dilakukan oleh kalangan Islam pada umumnya terutama kelompok Nahdlatul Ulama (NU). Hasyim 'Asy'ari, yang merupakan Pendiri NU, mengungkapkan bahwa ber- tawassul berarti memohon pertolongan Allah swt. melalui orang-orang yang memiliki drajat yang tinggi di sisi Allah swt. Karena ruh mereka jauh lebih suci. Yaitu para Nabi, wali dan orang-orang saleh.

Pandangan di atas sangat berbeda dengan pandangan klompok reformis, terutama Muhammadiyah dan Persatuan Islam. Mereka memandang, mengemudi pendahulunya Ibn Taimiyyah, bahwa tidak ada nash yang mengaruhi untuk memohon kepada Nabi dan kuburannya (memang pada kelompok tradisionalis pun tidak dianjurkan memohon kepada kuburan, hal itu memang dianggap menyalahi aturan agama, yang diperbolehkan adalah tawasul dan tabarruk, bukan memohon kepada kuburan). Tawassul yang dibolehkan hanya melalui nama dan sifat Allah, melalui amal saleh, dan memohon pada orang saleh yang masih hidup. Oleh sebab itu, kaum reformis cenderung menganggap musyrik kepada orang-orang yang bertawasul, meminta maaf, meminta ta'dzim dan tabarruk ke makam-makam Nabi, wali dan orang-orang saleh.

Melalui Tafsir Malja 'al-Talibin Sanusi membantah keras tuduhan klompok reformis tersebut. Menurutnya, makna tawassul tidak sesempit itu. Menurut Sanusi, orang reformis keliri dalam memahami tawassul dengan menyamakannya sepeerti penymbah berhala yang sampai drajat kufur. Bantahan Sanusi dapat dilihat pada tafsirnya ketika ia menafsirkan lafaz na'budu dan sata'inu sebagai berikut:

"Jadi salah kacida jeung trang- trangan kasasaran firqah anu nyebutkeun musyrik ka jalma anu ta'dzim tabaruk kana kuburan2 anbiya' shalihin, nyebutkeun pajar eta teh sarua reujeung ta'zimna tabarukna "ubad al-ashnam" kana berhala.

Kahiji, eta 'ubad al- ashnam nyebutna oge pangeran kana ashnamna. Kadua, ngaku manehanana henteu kawasa ibadah ka Allah ngan ukur kawasa ibadah ka ashnam. Katilu, maranehanna sok sujud ka ashnam. Kaopat, ana pareupeuncitan sok kalawan ngaran ashnam. Tah, ieu tingkah hnteu aya dina Muslimin anus ok tabaruk sok tawasul ka anbiya' salihin.

Menurut Sanusi, bertawasul dan memohon berkah kepada kuburan para Nabi dan para wali tidak sama dengan yang biasa dilakukan oleh penyembah berhala yang dituduhkan oleh kaum reformis yang didasarkan pada QS. al-Zumar (39): 3. Sanusi membedakan makna isti'anah secara hakiki (langsung kepada Allah) dan idafi. (melalui sandaran selain Allah). la member contoh dengan mengutup QS. al-Kahfi (18): 95; al-Qasas (28): 15; dan al-Maidah (5): 2. Dalam tafsir yang lainnya, yaitu Tamsijiatoel Moeslimin, ia juga dekat hal ini dengan ungkapan sebagai berikut:

"Tiada didjadikan soeatoe perantaraan di dalam haqeqatnja, diantara hamba dan Toehannja, djikalau si hamba meminta, maka ia meminta kepada Toehannja, tidak meminta kepada wakilnnja, atau koeasanja di dalam sehaqeqtnja".

Menurut Sanusi, wasilah secara hakiki berarti memohon lanagsung kepada Allah swt. sementara wasilah secara idafi berarti memohon do'a dan keberkahan pada selain Allah sebagai mana yang diperintahkan oleh Allah untuk saling membantu. Definisi tawassul seperti ini akhirnya dibantah oleh kelompok reformis seperti Mhd. Yunus dari Majelis Ahlu Sunnah Cilame (MASC) yang mengatakan bahwa yang dimaksud memohon bantuan kepada Allah di atas ayat di atas hanya dalam urusan yang dapat dilakukan oleh manusia. Urusan yang tidak dapat dilakukan oleh manusia, maka harus dipasrahkan kepada Allah swt. menurut Jajang A. Rohmana, kelompok reformasi cenderung memahami al-Qur'an secara sempit, sementara Sanusi memahaminya secara longgar.

Argumentasi lain yang dikemukakan Sanusi dapat dilihat ketika ia menafsrkan QS. al-Baqarah [2]: 125. Ayat ini dijadikan argumen bahwa Allah swt memerintahkan untuk bertawasul dan tabarruk pada kuburan para Nabi seperti shalat dekat maqam Ibrahim:

"(Watakhidu min maqami ibrahima musalla) kudu jieun pang salatan sakabeh jalma anu entas thawaf disunatken shalat dina deukeut eta batu dua rakaat. Henteu aya lian Gusti Allah marentah shalat didinya salain marentah tabaruk kana atsar2na salihin. Sabab aya tapakna kakasih Allah. Sedenga eta batu sok sumawona uraanag kuku tabaruk kana kuburan2 nabi ataw kana kuburan2 auliya lantaran etamah didinya aya bukti kakaasih Allah. Tah urang ngadu'a didinya deukeut kana dijabahna. Jadi kanyahoan salahna firqah anu ngufurkeun ka jalma anu tabaruk tawasul kalawan anbiya 
jeung auliya. Majarkeun hnteu beda reujeung tawasulna kufar kana ashnam anu maktak yakin salahna eta firqah karana maranehannana moal nyaruakeun tawasulna Muslim kalawan anbiya auliya kana tawasulna kufar kalawan ashnamna'udzu billah tsumma na'udzu billah. Padahal mah geuning hiji batu lantaran aya tapak Nabi eta diparentah ku Gusti Allah dialap berkah sakira2 diparentah shalat tukangeunnana" (Rohmana, 2017).

Pada QS. al-Kahfi: 95, mengisahkan Zulkarnain yang meminta bantuan kepada kelompok yang ada didekat dua gunung diantara Armenia dan Adzarbaizan atau gunung di Turki (menurut pendapat lain) ) (Al-Razi, n.d.). Hal ini, menurut Sanusi, merupakan contoh isti'anah idlafi.

"Ari Qur'an eta kalamna Allah eta qadim lain makhluk. Ari tta anu tilu puluh juz eta tulisan Qur'an eta tulisan anyar buatan jelema. Ari Qur'an anu ditulis eta qadim sabab eta tulisan lain 'ainna anu ditulis ari tulisan Qur'an eta Qur'an. Terangna ieu tawakuf ku nganyahokeun kana wujudna naon2 perkara eta aya oat: Kahiji, wujud 'ainna; Kadua, wujud tulisanna; Katilu, wujud bacaanna; Kaopat, wujud talaranna. Saperti seuneu wujud 'ainna nyaeta anu aya dina hawu nyaeta anu matak tutung. Ari wujud tulisanna nyaeta anu aya dina kertas kalawan hurup sin jeung nun sarta barisna peupeut, ari wujudna bacaan nyaeta anu aya dina letah nalika nyebut seuneu. Ari wujud talaranna nyaeta anu kacipta ku hate urang nalika ngingetkeun eta seuneu, karena lamun eta tulisan bacaan talaran seuneu 'ainna seuneu tangtu tutung kertasna letahna hatena. Ngan urang nyaho eta tulisan seuneu eta seuneu. Nyakitu bacaan seuneu eta seuneu. Tah nyakitu eta Qur'an, 'ainna eta sipat anu qadim, anu jumeneng dina zatna Allah, anu 30 juz eta tulisanna sarta tulisan Qur'n eta Qur'an. Wallahu a'lam".

Kutipan di atas menunjukan bahwa Sanusi merupakan ulama yang mengubah teologi Aswaja, khusunya dalam masalah keqadiman al-Qur'an. Menurut teologi Aswa al-Qur'an bukan makhluk dan al-Qur'an qadim, berbeda dengan Mu'tazilah yang mengatakan al-Qur'an makhluk dan hadis. Sekte yang lahir bebas pada saat teologi berjalan dengan ini mencoba mengajuka sebuah pandangan bahwa al- Qur'an ini hanya mushaf yang diciptakan oleh ruang dan waktu inilah kelompok Mu'tazilah mendudukan al-Qur'an hanya sebagai buku bacaan saja yang memberikan ruang interpretasi secara bebas tanpa adanya kungkungan doktrin apapun. Sanusi sebagai penganut Aswaja tentu memiliki kepentingan dalam wilayahnya terkait masalah ini (Rohmana, 2017).

\section{KESIMPULAN}

Dari pembahasan di atas dapat kita simpulkan bahwa Islam Tradisionalis adalah kelompok Islam yang mengkombinasikan ajaran Islam dengan adat kebiasaan daerah atau tradisi di dunia Islam. Kelompok ini berkembang mulai pada abad ke-20 yang merupakan reaksi terhadap kelompok Islam reformis yang kerap memberikan kritik terhadap tradisi kelompok masyarakat. Dalam konteks Indonesia, kelompok tradisionalis diwakili oleh organisasi masyarakat Nahdlatul Ulama (NU) tidak walaupun dipungkiri ada juga kelompok medernis yang tidak berorganisasi NU seperti Sanusi yang mendirikan organisasi sendiri. Mereka mengajarkan ajaran Islam melalui lembaga pendidikan tradisional yang disebut pesantren. Di pesantren ini mereka belajar tentang fikih, tauhid, tasawuf, tafsir dan ilmu-ilmu agama yang lainnya. Dalam kajian tafsir mereka pada umumnya hanya belajar Tafsir Jalalain. Meskipun ada sebagiannya yang mempelajari tafsir lain, namun hanya sebagian kecil saja. Dari pesantren-pesantren, mereka membentuk jaraingan sampai seluruh peloksok negeri. Penyebarannya dimulai dari masuknya Islam ke Sumatera pada abad 13 dan penyebaran Islam di Jawa oleh wali songo. Sejak menyebarnya Islam di Sumatera dan Jawa maka lahirlah para ulama taradisionalis yang menyiapkan pesantren di tiap daerah.

Asrama mengajar agama lisan, mereka juga mengajar agama lewat tulisan, dari mulai bidang fikih sampai bidang tafsir. Dalam bidang tafsir misalnya, mereka memberlakukan dan tertentu, yang berada di mushaf itu profane tidak sakral. Dengan presidensi anti-ideologi Aswaja, yang dilakukan oleh KH. Ahmad Sanusi. Dalam Tafsir Raudat al- 'Irfan dan Malja' al-Thalibin ia memuat kepentingan-keoentingan tradisionalis, baik fiqih maupun akidah. As ia wajib membahasnya membca fatihah dalam shalat, membahas al-Qur'an itu qadim dan membahas tawassul. Hal ini dilakukan sebagai respon terhadap kelompok modernis yang kerap melakukan kritik dan hujatan, bahkan sampai menganggap musyrik kelompok kepada kelompok tradisionalis.

\section{DAFTAR PUSTAKA}

Adeng, A. (2014). Pesantren Cipasung di Bawah Kepemimpinan Kh Ruhiat (Studi Keterlibatan Kiai dalam Perjuangan Kemerdekaan). Patanjala, 6(2), 253-268.

Afifulah. (2019). Metode pembelajaran tafsir perspektif sivitas pesantren: studi pada pesantren di Sumenep. UIN Sunan Ampel Surabaya.

Akbar, F. H., \& Rahmat, A. (2021). Kajian Analitik dan Epistemik Terhadap Corak Lughawī dan Kecenderungan I'tizāli Tafsir Al-Kasysyāf. Jurnal Iman Dan Spiritualitas, 1(1), 1-13.

Al-Razi. (n.d.). Mafatih al-Gaib. In Aplikasi Maktabah Syamilah.

Anwar, R., Darmawan, D., \& Setiawan, C. (2016). Kajian Kitab Tafsir Dalam Jaringan Pesantren Di Jawa Barat. Wawasan: Jurnal IImiah Agama Dan Sosial Budaya, 1(1), 56-69. 
Ari, A. W. W. (2019). Sejarah Tafsir Nusantara. Jurnal Studi Agama, 3(2).

Atabik, A. (2014). Perkembangan Tafsir Modern di Indonesia. Perkembangan Tafsir Modern Di Indonesia, 8, $318-322$.

Azra, A. (2019). Pendidikan Islam: Tradisi dan Modernisasi di Tengah Tantangan Milenium III. Prenada Media.

Batoro, J., Setiadi, D., Chikmawati, T., \& Purwanto, Y. (2013). Pengetahuan tentang tumbuhan masyarakat tengger di bromo Tengger semeru jawa timur. Wacana Journal of Social and Humanity Studies, 14(1), 1-10.

El Rahma, V. I. (2017). Sekular, Tradisionalis, dan Modernis (Sejarah, Karakteristik, dan Refleksinya di Indonesia). Syaikhuna: Jurnal Pendidikan Dan Pranata Islam, 8(1), 56-74.

Fadal, K. (2018). Genealogi dan Transformasi Ideologi Tafsir Pesantren. Jurnal Bimas Islam, 11(1), 73-104.

Fadlal, K. (2016). Studi Tafsīr Jalālain di Pesantren dan Ideologisasi Aswaja. Nun: Jurnal Studi Alquran Dan Tafsir Di Nusantara, 2(2), 26-54.

Huda, K. (2009). Fenomena Pergeseran Konflik Pemikiran Islam dari Tradisionalis vs Modernis ke Fundamentalis vs Liberalis. ISLAMICA: Jurnal Studi Keislaman, 3(2), 20-42.

Izzah, I. Y. U. (2011). Perubahan pola hubungan kiai dan santri pada masyarakat muslim tradisional pedesaan. Jurnal Sosiologi Islam, 1(2).

Kodir, A. (2015). Sejarah Pendidikan Islam. Bandung: Pustaka Setia.

Mufid, A. S. (2013). Paham Ahlu Sunnah Wal Jama'ah dan Tantangan Kontemporer dalam Pemikiran dan Gerakan Islam di Indonesia. Harmoni, 12(3), 8-18.

Rahman, M. T. (2016). Rasionalitas Sebagai Basis Tafsir Tekstual (Kajian atas Pemikiran Muhammad Asad). Al-Bayan: Jurnal Studi IImu Al-Qur'an Dan Tafsir, 1(1), 63-70.

Rahman, M. T., \& Mimbar, A. S. (2018). Konsep politik Islam kultural perspektif Nurcholish Madjid. FIKRI: Jurnal Kajian Agama, Sosial Dan Budaya, 3(2), 385-400.

Rohmana, J. A. (2017). Sejarah Tafsir Al-Qur'an di Tatar Sunda. Mujahid Press.

Sciortino, R., Marcoes Natsir, L., \& Mas' udi, M. F. (1996). Learning from Islam: advocacy of reproductive rights in Indonesian pesantren. Reproductive Health Matters, 4(8), 86-96.

Sukmadinata, N. S. (2019). Landasan psikologi proses pendidikan.

Syafrizal, A. (2015). Sejarah Islam Nusantara. Islamuna: Jurnal Studi Islam, 2(2), 235-253.

Tamam, A. B. (2018). Model Penelitian Tafsir; Studi Karya Howard M. Federspiel. Madinah: Jurnal Studi Islam, 5(2), $125-138$. Tim Prima Pena. (2012). Kamus Besar Bahasa Indonesia Edisi Terbaru. Gita Media Press.

Ukhriyati, D. (2017). Ajaran Makrifat Sunan Kalijaga dan Syekh Siti Jenar. UIN Syarif Hidayatullah Jakarta: Fakultas Ushuluddin, 2017.

Van Bruinessen, M. (1995). Kitab kuning pesantren dan tarekat: tradisi-tradisi islam di Indonesia. Mizan.

Wahid, K. A., Paige, G., \& Rahman, M. T. (1998). Islam tanpa kekerasan. LKiS.

Wibisono, M. Y. (2020). Sosiologi Agama. Prodi P2 Studi Agama-Agama UIN Sunan Gunung Djati Bandung.

Zulaeha, E. (2020). Prinsip Liberalisme dalam Metodologi Tafsir Feminis: Pembacaan pada Karya-karya Husein Muhammad. Khazanah: Jurnal Studi Islam Dan Humaniora, 18(1), 25-48.

Zulaiha, E. (2017). Tafsir Kontemporer: Metodologi, Paradigma dan Standar Validitasnya. Wawasan: Jurnal IImiah Agama Dan Sosial Budaya, 2(1), 81-94.

(C) 2021 by the author. Submitted for possible open access publication under the terms and conditions of the Creative Commons Attribution (CC BY SA) license (http://creativecommons.org/licenses/by-sa/4.0/). 